\title{
Characterization of cordierite-mullite ceramics prepared from natural raw materials
}

\author{
Abdulmula Ali Albhilil, Martin Palou, Jana Kozánková \\ Faculty of Chemical and Food Technology, Institute of Inorganic Chemistry, Technology and materials, \\ STU Bratislava, Radlinského 9, 81237 Slovak Republic martin.palou@stuba.sk
}

\begin{abstract}
Series of six cordierite-mullite ceramics were synthesized via solid state reaction at various temperatures from $1250^{\circ} \mathrm{C}$ for pure cordierite to $1500^{\circ} \mathrm{C}$ for pure mullite. Then the samples were submitted to the test of thermal shock resistance based on cycling heating-quenching procedure. X-ray diffraction (XRD), Scanning electron microscopy (SEM) and Mercury intrusion porosimeter (MIP) have been used to characterize the samples before and after cycling heating-quenching method. Sample 6 was broken after 35 heating-quenching cycles, while the five other reminded stable. The refractoriness of samples is found to be higher than that of commercial ones. XRD shows that heating-quenching procedure has led to crystallization of cordierite and mullite phases. Apart from sample 6, the pore structure is stable with slight consolidation. The microstructure images confirm the results of XRD and MIP showing crack in sample 6 only, but compact and larger particles resulting from crystal growth in other samples due to the repeated action of heating.
\end{abstract}

Keywords: cordierite-mullite, thermal resistance, microstructure, pore structure

\section{Introduction}

Ceramics materials based on cordierite are of great importance as refractory and other technical ceramic materials due to their low thermal expansion coefficient, excellent thermal shock resistance, low dielectric constant, high refractoriness and high mechanical strength. These ceramics are used in various industrial fields, such as refractories for industrial furnaces, electrical, thermal or phonic insulation, filters, membranes, heating elements, microwave absorbents electromagnetic waves absorbents or as substrate for integrated circuit boards (Naskar and Chatterjee 2004; Gonzalez-Velasco et al. 1999; Sugiura and Kuroda 1955; Evans et al. 1980). Cordierite with chemical composition of $(\mathrm{Mg}, \mathrm{Fe})_{2} \mathrm{Al}_{4} \mathrm{Si}_{5} \mathrm{O}_{18}$ is a magnesium aluminosilicate mineral, occurring very rarely in nature. With regard to the large field of application in industrial area, synthetic and natural materials based on magnesium, aluminum and silicon oxides were employed to produce cordierite ceramics (Suzuki et al. 1987; Goren et al. 2006; Ozgur and Gocmez 2006; Yuichi et al. 2000, Cristina et al. 2007). Several methods were developed and applied to synthesize cordierite ceramics. Among other, solid state sintering reaction (Cristina et al. 2007), sol gel method (Kumta et al. 1994), plasma spraying (Rohana $e t$ al. 2004) or crystallization from glasses (Rudolph et al. 1993) was frequently used. The natural materials are talc, china clay, kaolin, magnezite and quartz. The presence of impurities in natural raw materials has helped sintering process. However, due to fact that the natural mineral is not abundant or pure enough, advanced ceramics based on cordierite for special applications have to be synthesized form the ternary oxide system $\mathrm{MgO}-\mathrm{Al}_{2} \mathrm{O}_{3}-\mathrm{SiO}_{2}$. This system is characterized by two main minerals; cordierite $\left(2 \mathrm{MgO} \cdot 2 \mathrm{Al}_{2} \mathrm{O}_{3} \cdot 5 \mathrm{SiO}_{2}\right)$ and mullite $\left(3 \mathrm{Al}_{2} \mathrm{O}_{3} \cdot 2 \mathrm{SiO}_{2}\right)$ that form the base of technical ceramics (Kingery 1960; Hlaváč 1988). The studies of phase equilibrium undertaken by (Petrovic et al. 2002) have shown that cordierite exists in three polymorphs: $\alpha$-cordierite (indialite), stable between $1450{ }^{\circ} \mathrm{C}$ and $1460{ }^{\circ} \mathrm{C}, \beta$-cordierite, stable at temperatures lower than $1450{ }^{\circ} \mathrm{C}$ and $\mu$-cordierite, metastable. The polymorphism and stoichiometry of cordierite is complicated. For stoichiometric cordierite, the high temperature form is hexagonal. Below $1450{ }^{\circ} \mathrm{C}$, cordierite is metastable and it is slowly transforms to $\beta$ or low cordierite. Therefore, polycrystalline cordierite with high strength, high density and low thermal expansion coefficient (TEC) of stoichiometric composition, $2 \mathrm{MgO} \cdot 2 \mathrm{Al}_{2} \mathrm{O}_{3} \cdot 5 \mathrm{SiO}_{2}$, is difficult to obtain. Pure cordierite with density $2.53 \mathrm{~g}$. $\mathrm{cm}^{3}$ melts at $1470{ }^{\circ} \mathrm{C}$ (Smart and Glasser 1981).

Mullite is another important ceramic material in $\mathrm{MgO}-\mathrm{Al}_{2} \mathrm{O}_{3}-\mathrm{SiO}_{2}$ system (Kingery 1960) with nonstoichiometry and average composition ranging from $3 \mathrm{Al}_{2} \mathrm{O}_{3} \cdot 2 \mathrm{SiO}_{2}$ to $3 \mathrm{Al}_{2} \mathrm{O}_{3} \cdot \mathrm{SiO}_{2}$. Mullite has a defect structure based on oxygen vacancies. The oxygen vacancies can order to varying degrees and high alumina mullite are often referred to as having a tetragonal structure. In the entire temperature range of the crystalline phase, there are no polymorphic transitions that would lead to volumetric changes (Schneider and Eberhard 1990; Schneider and Schreuer 2008). Pure mullite $\left(3 \mathrm{Al}_{2} \mathrm{O}_{3} \cdot 2 \mathrm{SiO}_{2}\right)$ has an orthorhombic crystal lattice, its density is $3.0 \mathrm{~g} \mathrm{~cm}^{-3}$ and melting point $1810{ }^{\circ} \mathrm{C}$. Mullite ce- 
ramic materials have the same advantages in applications like cordierite ones, but with higher thermal and chemical stability at high temperatures. Therefore, low in intrinsic strength of cordierite due to polymorphism transformation can be compensated by the presence of mullite $\left(3 \mathrm{Al}_{2} \mathrm{O}_{3} \cdot 2 \mathrm{SiO}_{2}\right)$ in spite of some increase in the thermal expansion coefficient results. Mullite ceramics were synthesized via sol-gel process from commercial Boehmite and Tosil (Pach et al. 1996), from natural and secondary raw materials (Yingchao et al. 2008; Yingchao et al. 2011). Mullite itself is an excellent refractory material with good thermal shock resistance and it has a thermal expansion coefficient of about $5.4 \times 10^{-6}{ }^{\circ} \mathrm{C}^{-1}$. Then, the cordierite-mullite composite material can exhibit high thermal and mechanical strength at service temperatures below $1300{ }^{\circ} \mathrm{C}$ (Naskar and Chatterjee 2004). Cordierite-mullite ceramics not only can have good high-temperatures properties, but also excellent electrical insulating ability making them potentially useful in applications ranging from technical refractories to functional and structure ceramics (R. Gopi et al. 1995; Hodge 1989; Ebadzadeh and Lee 1998). Ceramics based on cordierite and mullite can be used as refractory (kiln lining, gas burners with low dielectric constant, high resistivity, elevated thermal and chemical stability, very low thermal expansion coefficient and good thermal shock resistance (Mussler and Shafer 1984). The main raison of the present study is the exploration of potential use of natural raw materials from Libya to prepare refractory materials. The choice of cordierite and/or mullite and their composites was motivated by availability and purity of Libyan kaolin, quartz, dolomite, magnezite and limestone that can be used for the production of industrial refractory materials with minimal addition of pure oxide components. In this study; binary cordierite-mullite composites at various compositions were prepared at different temperatures. As a result materials with variety of microstructural, physical and thermal properties were obtained and characterized.

\section{Experimental}

The starting materials used to prepare cordieritemullite ceramics were natural kaolin from Sabha (Southwestern Libya) and Quartz from Al-ziziyah (Northwestern Libya). The chemical composition of natural raw materials from Libya (3 samples of kaolin, 3 samples of sand, 2 samples of dolomite and limestone) was analyzed by the State authorized Slovak Geological Laboratory in Spišská Nová Ves, using X-ray fluorescence. The chemical composition of used raw materials summarized in Table 1.
Natural magnesite of high purity is from Slovak Company "Slovenské magnezitové závody, akciová spoločnoste, Jelšava, Slovak Republic”.

The composite cordierite-mullite ceramics were obtained by high temperature solid state reaction of mixtures, in which natural kaolin, quartz, magnesite, and reagent grade aluminum hydroxide from Sigma-Aldrich were used as raw materials for the synthesis.

Tab. 1. The chemical compositions of kaolin and quartz (wt. \%), determined by X-ray Fluorescence at geological laboratory and magnezite given by Plant

\begin{tabular}{|c|c|c|c|}
\hline \multirow{2}{*}{ Oxide } & \multicolumn{3}{|c|}{ Natural raw materials } \\
\hline & Kaolin & Quartz & Magnezite \\
\hline $\mathrm{SiO}_{2}$ & 54.7 & 96.5 & 1.28 \\
\hline $\mathrm{Al}_{2} \mathrm{O}_{3}$ & 29.3 & 1.71 & 0.2 \\
\hline $\mathrm{Fe}_{2} \mathrm{O}_{3}$ & 1.68 & 0.13 & 1.70 \\
\hline $\mathrm{CaO}$ & 0.10 & 0.09 & 1.08 \\
\hline $\mathrm{MgO}$ & 0.19 & 0.10 & 45.35 \\
\hline $\mathrm{TiO}_{2}$ & 1.75 & 0.04 & - \\
\hline $\mathrm{MnO}$ & $<0.01$ & $<0.01$ & - \\
\hline $\mathrm{K}_{2} \mathrm{O}$ & 0.58 & 0.77 & - \\
\hline $\mathrm{Na}_{2} \mathrm{O}$ & 0.20 & $<0.2$ & - \\
\hline $\mathrm{P}_{2} \mathrm{O}_{5}$ & 0.05 & $<0.01$ & - \\
\hline L. O. I at $1000^{\circ} \mathrm{C}$ & 11.1 & 0.33 & 50.40 \\
\hline
\end{tabular}

\section{Preparation of cordierite - mullite composites}

Six mixtures were prepared to obtain cordierite-mullite with different. Fristly, the mixtures of raw materials were prepared in $\mathrm{MgO} \cdot \mathrm{Al}_{2} \mathrm{O}_{3} \cdot \mathrm{SiO}_{2}$ molar ratio of 2:2:5 for pure cordierite and in $\mathrm{Al}_{2} \mathrm{O}_{3} \cdot \mathrm{SiO}_{2}$ molar ratio of 3:2 for pure mullite. Then, series of different mixtures corresponding to different ratio of cordierite-mullite ceramics have been set as shown in Table 2. After mixing and homogenizing process, $50 \mathrm{~g}$ of powder of different mixtures was mixed with water to form paste and hand pressed in a cylindrical die with dimension of $\varnothing 25 \mathrm{~cm}$. After drying, the samples were sintered in electrical furnace at different temperatures from $1250{ }^{\circ} \mathrm{C}$ to $1500{ }^{\circ} \mathrm{C}$ for $1 \mathrm{~h}$ using heating rate $10 \mathrm{~K} \mathrm{~min}^{-1}$.

\section{Characterization Procedure and Techniques}

Samples were submitted to the shock thermal resistance by quenching method. The samples were dried at $110{ }^{\circ} \mathrm{C}$ and then heated in an electric furnace at $1100{ }^{\circ} \mathrm{C}$ for 1 hour. Then the samples were dropped into water bath having temperature of $2{ }^{\circ} \mathrm{C}$, left there for a few seconds and dried again at $110^{\circ} \mathrm{C}$ before returning to the furnace. This procedure was repeated until apparition of first cracks or defects on the surface of the first sample. 
Tab. 2. Composition of cordierite-mullite ceramics, sintering temperatures and detected phases.

\begin{tabular}{|c|c|c|c|c|c|c|c|}
\hline \multirow{3}{*}{ Temperature } & \multicolumn{7}{|c|}{ Composition of cordierite/mullite ceramics (\%) and identified phases } \\
\hline & Cordierite & $100 \%$ & $80 \%$ & $60 \%$ & $40 \%$ & $20 \%$ & $0 \%$ \\
\hline & Mullite & $0 \%$ & $20 \%$ & $40 \%$ & $60 \%$ & $80 \%$ & $100 \%$ \\
\hline $1250^{\circ} \mathrm{C}$ & Sample 1 & $\mathrm{C}, \mathrm{M}, \mathrm{Q}$ & & & & & \\
\hline $1300^{\circ} \mathrm{C}$ & Sample 2 & & $\mathrm{C}, \mathrm{M}, \mathrm{S}, \mathrm{Q}$ & & & & \\
\hline $1350^{\circ} \mathrm{C}$ & Sample 3 & & & $\mathrm{C}, \mathrm{M}$ & & & \\
\hline $1400^{\circ} \mathrm{C}$ & Sample 4 & & & & $\mathrm{M}, \mathrm{S}$ & & \\
\hline $1450^{\circ} \mathrm{C}$ & Sample 5 & & & & & M, S & \\
\hline $1500^{\circ} \mathrm{C}$ & Sample 6 & & & & & & $\mathrm{M}, \mathrm{S}$ \\
\hline
\end{tabular}

C - Cordierite $\left(2 \mathrm{MgO} \cdot 2 \mathrm{Al}_{2} \mathrm{O}_{3} \cdot 5 \mathrm{SiO}_{2}\right), \mathrm{M}-$ Mullite $\left(3 \mathrm{Al}_{2} \mathrm{O}_{3} \cdot 2 \mathrm{SiO}_{2}\right), \mathrm{S}-$ Sillimate $\left(\mathrm{Al}_{2} \mathrm{O}_{3} \cdot \mathrm{SiO}_{2}\right), \mathrm{Q}-$ Quartz $\left(\mathrm{SiO}_{2}\right)$.

The crystal phases of the samples were identified by XRD analysis (STOE, type theta/theta diffractometer).

Microstructural characterization of the sintered samples before and after thermal shock test was carried out using scanning electron microscope SEM (TESLA BS 300 with digital unit TESCAN).

The pore structure (particle size distribution-PSD) before and after thermal shock test was measured at Slovak Academy of Sciences by Mercury Intrusion Porosimetry (MIP) using Quantachrome Poremaster $60 \mathrm{GT}$.

\section{Results and discussion}

\section{XRD Analysis}

The formation of cordierite-mullite and other crystalline phases in samples sintered at different temperatures through $1250-1500 \mathrm{C}^{\circ}$ and submitted to heating-quenching cycles were analyzed by XRD analyses. The results are summarized in Table 2. Mullite and quartz are found in almost all samples sintered at lower temperatures. This is due to difficulties of solid state reaction in general, but the main reason can be explained by mineralogical and chemical composition of natural raw materials. Indeed, natural raw materials, apart from the main oxides $\left(\mathrm{Al}_{2} \mathrm{O}_{3}, \mathrm{SiO}_{2}\right.$, and $\left.\mathrm{MgO}\right)$, contain also some minor oxides $\left(\mathrm{CaO}\right.$, alkalis, $\left.\mathrm{Cr}_{2} \mathrm{O}_{3}\right)$ which can greatly influence the course of reaction.

Figure 1 and Figure 2 depict the XRD patterns of pure cordierite and pure mullite, before and after cycling. The formation of cordierite phases is related with the starting raw materials. The first peak characterizing the presence of cordierite (maximum intensity peak (110) corresponds to $2 \theta=12.46$ ) appears at $1250{ }^{\circ} \mathrm{C}$. This peak increased after 35 heating-quenching cycles (Fig. 1). It is clear that cordierite is mostly in crystalline phase, as it can be observed on microstructure. The solid state reaction of mixtures consists of step reaction starting with the formation of spinel at about $1040{ }^{\circ} \mathrm{C}$ (Naskar and Chatterjee 2004). As temperature increases, spinel reacts with cristobalite at about $1350{ }^{\circ} \mathrm{C}$ to form cordierite. The fact that the dominant phase is cordierite proves the reliability of the preparation

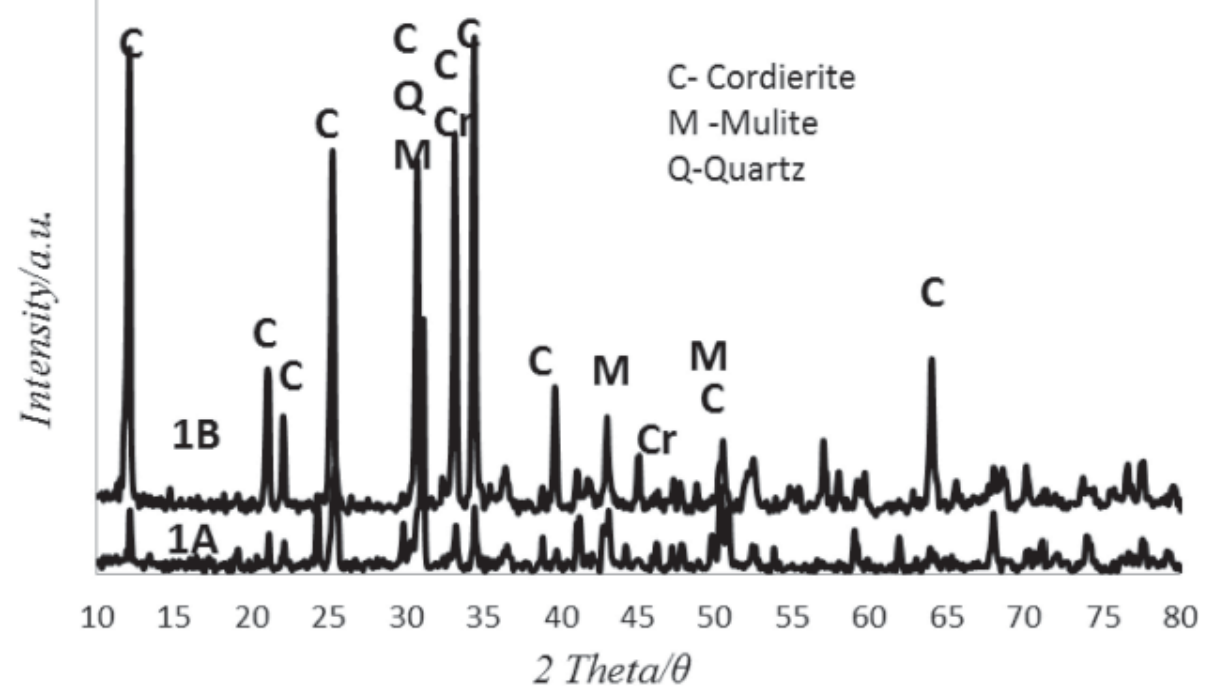

Fig. 1. XRD patterns of sample before (bottom - 1A) and after thermal shock test (top - 1B). 


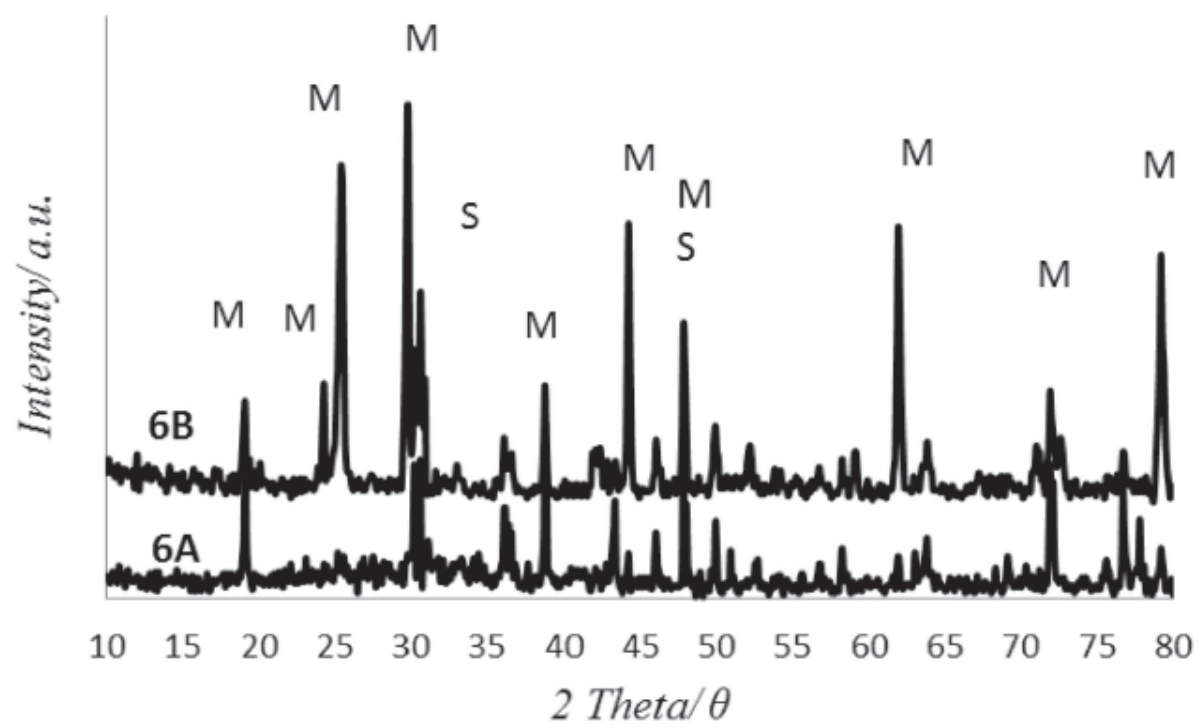

Fig. 2. XRD patterns of sample before (bottom $-6 \mathrm{~A}$ ) and after thermal shock test (top $-6 \mathrm{~B}$ ).

of refractory cordierite ceramics from natural raw materials and confirms the accuracy of mixture calculation. After 35 cycles of heating-quenching cycles, cordierite is well crystallized, but mullite and quartz still remain. Cordierite content increases with increasing temperature, while $\mathrm{SiO}_{2}$ decreases and it is transformed into cristobalite. The presence of quartz at lower temperature and cristobalite at higher ones results from the kinetics of solid state reaction due to factors like finesses of the powder including its particle distribution, nonhomogenity and reactivity of quartz.

The XRD pattern of sintered mixture for the preparation of pure mullite ceramics before and after cycling is reported in Fig. 2. The first peak characterizing mullite has been found at $1250^{\circ} \mathrm{C}$. The compositions sintered at $1500{ }^{\circ} \mathrm{C}$ for $1 \mathrm{~h} \mathrm{ex}$ hibit the XRD pattern corresponding to mullite supplemented by sillimanite that is another form of alumina-silicate.

\section{Results of Thermal Shock Resistance}

After sintering and XRD analysis the samples were submitted to thermal shock resistance test by simple modified ASTM, C 1171-91 heating-quenching method. The cycles were repeated several times until the apparition of the first damage on the first samples. 35 cycles of heating-quenching were carried out before the sample 6 was broken. The number of cycles of thermal shock resistance characterizing the refractoriness of ceramics varies from materials to materials and depends on the temperature. Number 8 to 30 can be found in literature (Zdeněk et al. 2006). Water quench results showed that samples were stable till 34 cycles.

After thermal shock test, samples were analyzed by SEM to examine the damage caused at micro- structure level. As illustration, microstructure image of sample 1 and sample 6 before (A) and after $35^{\text {th }}$ heating-quenching cycle (B) are presented in Figure 3. The effect of thermal shock is evidenced by the apparition of crack in the microstructure of sample 6 , while none sign of damage was observed in sample 1, likewise for other samples. The microstructure of samples has changed from glass to crystallized phases after thermal shock test.

\section{MIP of samples before and after heating-quenching test}

After thermal shock test, samples were submitted to mercury intrusion porosimetry measurement to identifier the modifications occurred during the heating-quenching cycles in the pore structure. Original samples were also analyzed and the particle size distribution-PSD of samples before and after thermal shock test are depicted on Figure 4. It is evident that the pore structure changes with cordierite-mullite composition. With addition of mullite to $60 \mathrm{wt}$. \%, pore structure becomes finer and PSD is shifted towards higher mercury pressure. The two last samples present some uncommon PSD characteristics with bimodal repartition for sample 6. These samples were found more friable after preparation and will necessitate the use of melting additive in order to consolidate the pore structure. The PSD of sample after thermal shock test give an evidence of sample stability after heating-quenching cycles.

\section{Conclusion}

The obtained results of preparation of cordieritemullite ceramics from natural raw materials enable us to draw the following conclusion: 


\section{Before cycling}

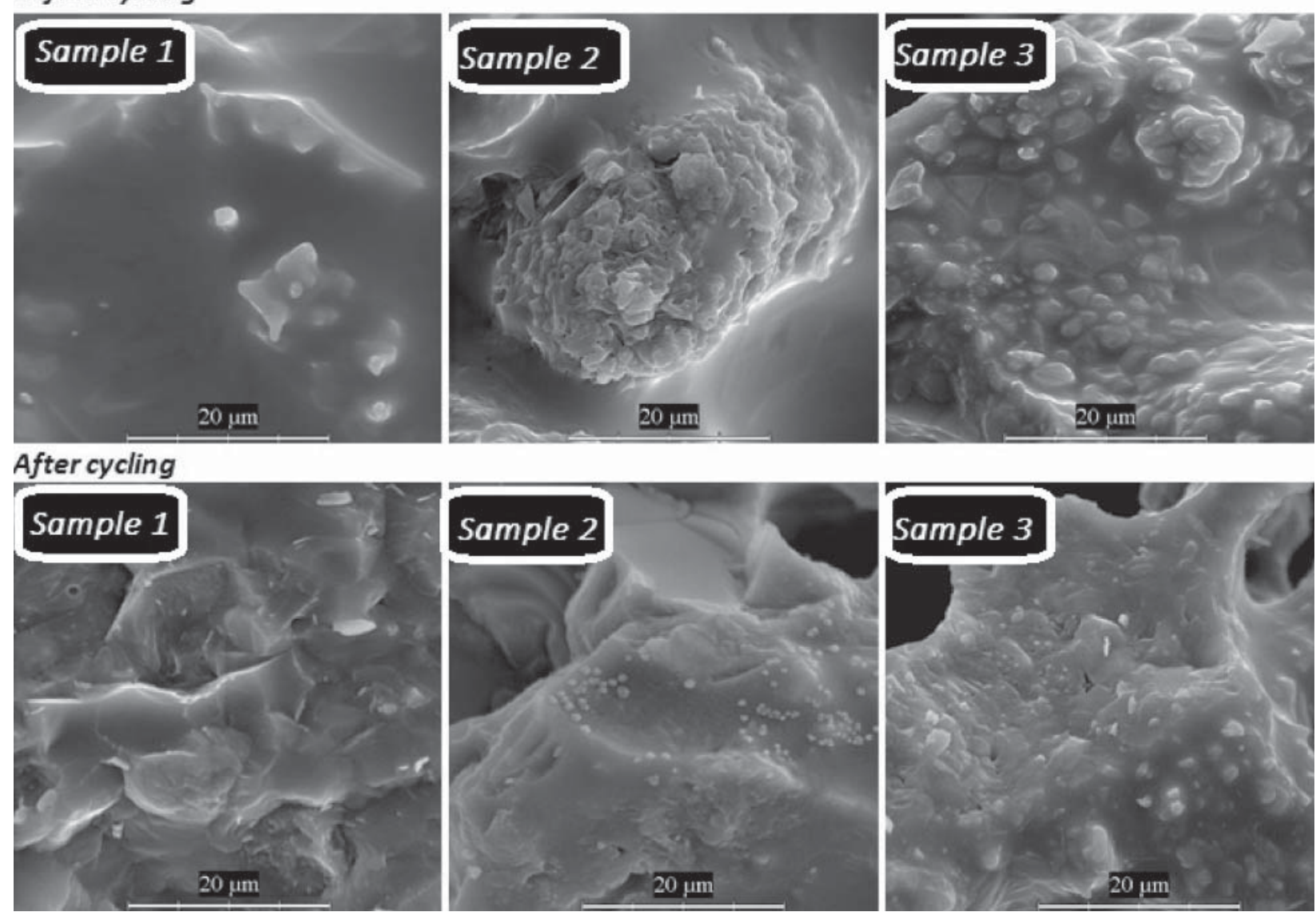

\section{Before cycling}

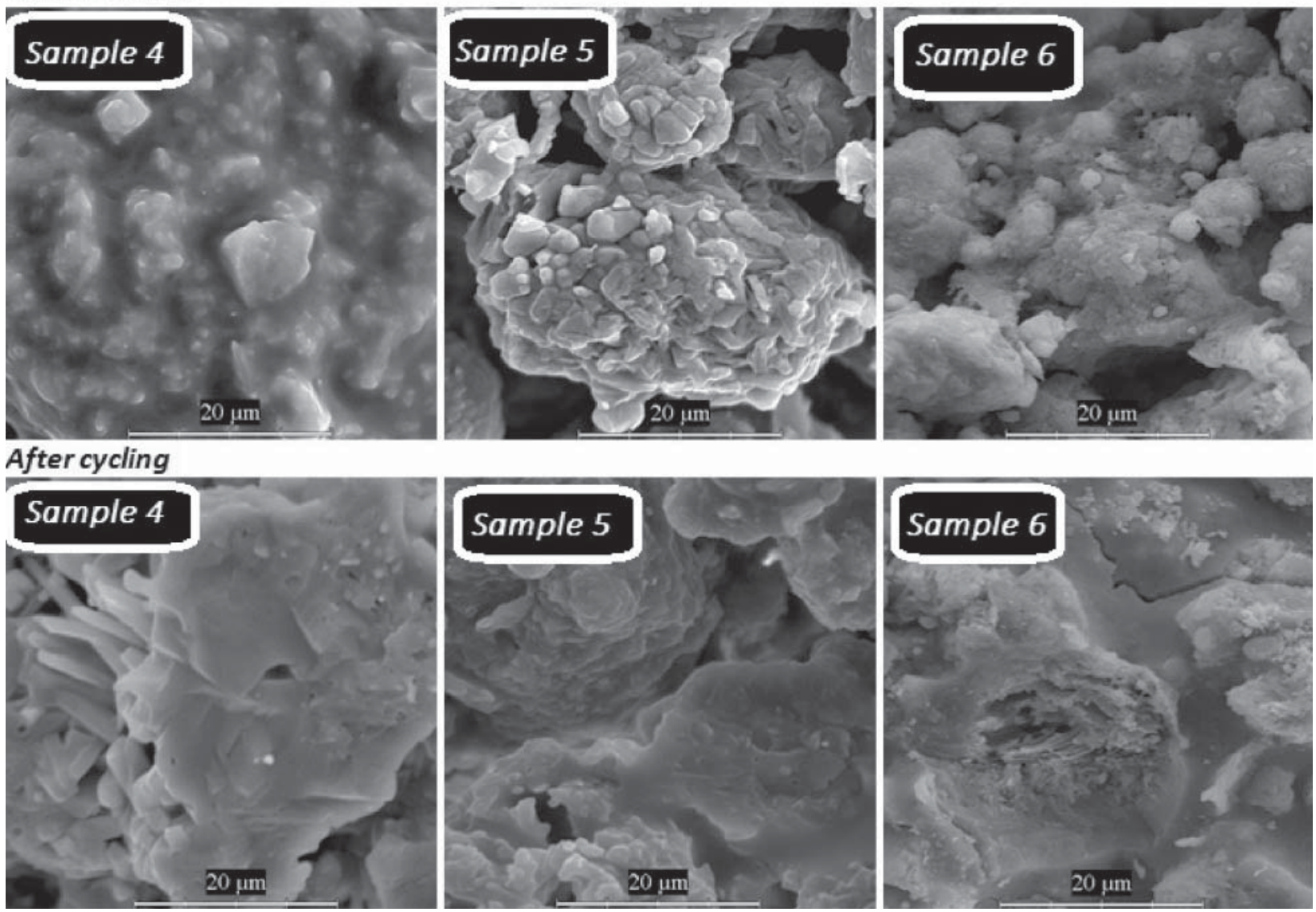

Fig. 3. Microstsructure of Sample 1 to Sample 6 before and after 35 cycles of heating-quenching. 

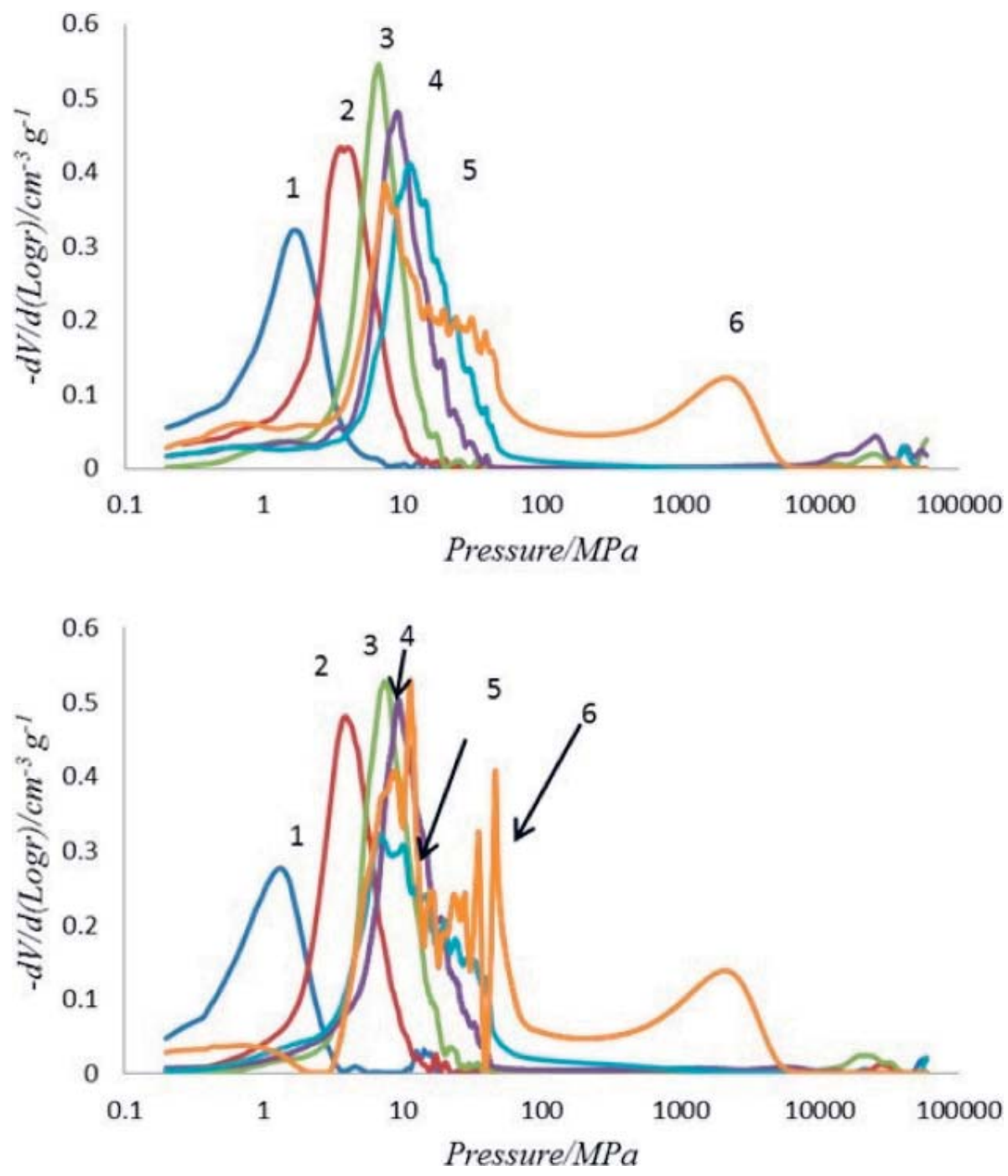

Fig. 4. PSD of sample 1-6 before (top - A) and after (bottom - B) 35 cycles of heating-quenching.

1. Natural kaolin, quartz and magnesite with minimum addition of pure boehmite can be used to prepare ceramics with different cordieritemullite ratio.

2. The optimal temperature for preparation depends on cordierite-mullite ratio.

3. Thermal shock method based on heating and quenching has proved the thermal stability of samples till $35^{\text {th }}$ cycles.

4. Scanning electron analysis and porosimeter analysis has not revealed significant change in microstructure and pore structure characteristics between samples before and after thermal shock test.

\section{Acknowledgment}

This research was made possible thanks to Libyan Government. The authors are also grateful to the VEGA grant No. 1/0934/11.

\section{References}

Cristina G, Ecaterina A, Oana N, Dicea A, Mihaela B (2007): J. Eur. Ceram. Soc. 27: 711-713.

Ebadzadeh T, Lee W E (1998): J. Eur. Ceram. Soc.18: 837-848.

Evans DL, Ficher GR, Geiger JE, Martin FM (1980): J. Am. Ceram. Soc. 63: 629-634.

Goren R, Ozgur C, Gocmez H (2006): Ceramics International. 32: 53-56.

Gonzalez-Velasco JR, Gutierrez-Ortiz MA, Ferret R (1999): J. Mater. Sci. 34: 1999-2002.

Hlaváč 1988. Základy technologie silikátů SNTL ALFA, Praha, Czech Republic, (in Czech, Elements of Silicate Technology).

Hodge JD (1989): J Am. Ceram, Soc. 72: (7) 1295-1298.

Kingery WD (1960): Introduction to Ceramics. John Wiley and Sons, New York.

Kumta PN, Hackenberg RE, McMichael P, Johnson WC (1994): Mat. Lett. 20: 355-362.

Mussler BH, Shafer MW (1984): Ceram, Bull. 65: (3) $705-710$. 
Naskar MK, Chatterjee M (2004): J. Eur. Ceram. Soc. 24: 3499.

Pach L, Iratni A, Kovar V, Mankoš P, Komarneni S (1996): J. Eur. Ceram. Soc. 16: 561-565.

Petrovic R, Janackovic DJ, Zec S, Drmanic S. and KosticGvozdenovic Lj (2002): Mater. Res. 16: 26.

Rohana P, Neufussa K, Matějíček J, Dubskýa J, Prchlík L, Holzgartner C (2004): Ceramics International. 30 597-603.

Rudolph T, Pannhorst W, Petzow G (1993): Journal of Non-Crystalline Solids 155: 273-281.

R.Gopi CH, Patil KC, Chandrappa GT (1995): J. Mater. Sci. Lett. 14: 548-555.

Smart RM, Glasser FP (1981): Ceram. Inter. 7: (3) 90-97.

Schneider H, Eberhard E (1990): J. Am. Ceram. Soc. 73 (7) 2073-2076.
Schneider H, Schreuer J, Hildmann B (2008): J. Eur, Ceram. Soc. 28: 329-344.

Sugiura K, Kuroda Y (1955): J. Ceram. Soc. Jpn. 63: $579-582$.

Suzuki H, Ota K, Saito H (1987): J. Ceram. Soc. Japan (Yogyo-Kyokai-Shi) 95: (2) 163-169.

Yingchao D, Xuyong F, Xuefei F, Yanwei D, Xingqin L, Guangyao M (2008): Journal of Alloys and Compounds. 460: 599-606.

Yingchao D, Stuart H, Jian-er Z, Zhanlin J, Jiandong W, Guangyao M (2011): J. Eur. Ceram. Soc. 31: 687-695.

Yuichi K, Katsuhiro S, Etsuro K (2000): Ceramics International. 26: 739-743.

Zdeněk C, Dino NB, Cristina L, Marcello R, Aldo RB (2006): Ceram.-Silik. 50: (4) 245-250. 